\title{
ACKNOWLEDGING LAND RIGHTS OF THE ORANG ASLI: A HISTORICAL PERSPECTIVE OF LAWS IN PENINSULAR MALAYSIA
}

\author{
Izawati Wook*
}

\begin{abstract}
The perspective that the Orang Asli communities do not have legal rights to their customary land remains despite common law recognition by the courts in a series of cases since two decades ago. To the contrary, this article argues that such a perspective has no basis under the law. By using a historical research approach, it is shown that it has never been the case under the law, policy and practices that the customary land of the Orang Asli was denied their entitlement. In practice, the law and official policy and their development in history observe and acknowledge the existing rights to land and resources, which arose from custom of the local inhabitants including the Orang Asli. The law inherently recognises the Orang Asli as having their own distinct political and social identities. The article provides a historical perspective of law and official practices in the Malay Peninsula in relation to land rights of the Orang Asli and trace their origin to British conduct in North America and the Indian Empire which directly influenced their actions in the Malay states. The reality is that, rather than the denial of the land rights of the Orang Asli under the law, there were other factors that led to the continued loss of their land. Conflicting economic interests and cultural attitudes compounded by a change towards legal positivism that came to prevail both, in international law and national legal systems, hampered the recognition of law relating to the land rights of the Orang Asli, who are a minority group that lacks political power. Following this argument, the development of Malaysian common law, beginning from the case of Adong bin Kuwau v Kerajaan Negeri Johor in 1997 that addressed the concerns of the Orang Asli, as well as the natives in East Malaysia, is not novel; it is merely the application of a long standing legal principle in the jurisdiction.
\end{abstract}

Senior Lecturer, Faculty of Syariah and Law, Universiti Sains Islam Malaysia, izawati@usim.edu.my or izawati.wook@gmail.com. 
Keywords: legal history, historical research, Malaysia, indigenous peoples, orang asli, Aboriginal Peoples Act 1954

\title{
MENGIKTIRAF HAK-HAK TANAH ORANG ASLI: PERSPEKTIF SEJARAH PERUNDANGAN DI SEMENANJUNG MALAYSIA
}

\begin{abstract}
ABSTRAK
Perspektif yang menyatakan bahawa tanah adat yang diduduki oleh Orang Asli tidak diiktiraf oleh undang-undang masih didengari sungguhpun common law di Malaysia telah pun mengiktiraf hak tersebut melalui beberapa siri kes sejak 2 dekad yang lalu. Sebaliknya, makalah ini menghujahkan bahawa perspektif tersebut tidak mempunyai asas dalam undang-undang. Dengan menggunakan pendekatan penyelidikan yang berasaskan sejarah, makalah ini menunjukkan bahawa undang-undang, polisi dan amalan berkaitan tidak pernah menafikan pemilikan tanah adat oleh masyarakat Orang Asli. Malahan, undang-undang dan polisi yang diamalkan, serta perkembangannya dalam sejarah memerhatikan dan secara tersirat menghormati hak penduduk asal sedia ada termasuk Orang Asli terhadap tanah dan sumber semulajadi yang terbit dan diperkukuhkan melalui tradisi dan amalan yang membentuk adat. Undang-undang yang telah digubal memperakui kedudukan Orang Asli sebagai satu identiti tersendiri dari sudut politik dan sosial. Bagi tujuan tersebut, makalah ini membincangkan berkenaan perkembangan undang-undang dan amalan pentadbiran di Semenanjung Tanah Melayu yang menyentuh tentang hak tanah dan Orang Asli. Tema ini dapat dilihat dengan menelusuri asal usul amalan British di Amerika Utara dan Empayar British di India yang telah memberi kesan langsung terhadap tindak-tanduk pemerintahan British di negerinegeri Melayu. Oleh itu, realitinya adalah, bukanlah undang-undang yang telah menafikan hak Orang Asli terhadap tanah adat mereka, namun faktor-faktor lain yang telah membawa kepada pengurangan dan kehilangan tanah milik masyarakat pribumi ini termasuk pelbagai kepentingan politik dan perspektif budaya. Apatah lagi, perubahan dalam konteks undang-undang yang perlahan-lahan menekankan kepada ide positivism di dalam undang-undang bukan saja di peringkat antarabangsa tetapi juga dalam negara telah
\end{abstract}


memberi kesan kepada pengiktirafan tersirat undang-undang terhadap hak masyarakat pribumi. Dari sudut pandang ini, pembentukan common law di Malaysia bermula dengan kes Adong bin Kuwau v Kerajaan Negeri Johor in 1997 sejak 2 dekad lalu yang mengiktiraf hak tanah masyarakat Orang Asli dan pribumi di Sabah dan Sarawak bukanlah sesuatu perkembangan yang baru, sedangkan ianya hanyalah pemakaian prinsip perundangan yang telah kukuh di dalam perundangan di negara ini.

Kata kunci: sejarah perundangan, penyelidikan sejarah, Malaysia, orang asal, orang asli, Akta Orang Asli 1954 


\section{INTRODUCTION}

The customary land rights of the Orang Asli have received judicial recognition in a series of cases. ${ }^{1}$ Since 1997, the courts, beginning with the decision of Adong bin Kuwau v Kerajaan Negeri Johor ${ }^{2}$ has established the common law principle of recognition of native title or land rights, not only of the Orang Asli in Peninsula Malaysia but also the natives of East Malaysia. ${ }^{3}$ It has been affirmed that the Orang Asli have common law rights to their ancestral lands that they have occupied since time immemorial. These Land rights are proprietary rights with full beneficial interests in, and to, the land. The land is therefore inheritable, that is, capable of being passed down from generation to generation. ${ }^{4}$ Despite these rulings, the perspective that the Orang Asli or the aboriginal peoples do not own their customary land but live on state land as tenants-at-will continues to this day. Many still believe that the communities' occupation of their customary land is only subject to discretion of state authorities under the Aboriginal Peoples Act 1954 (APA 1954) which even allows for unilateral removal. ${ }^{5}$

This article considers the basis of this perspective from a historical research approach. Historical research examines past events by using a variety of primary and secondary sources to defend or

1 Adong Bin Kuwau V Kerajaan Negeri Johor, 1 MLJ 418 (1997). Kerajaan Negeri Johor V Adong Bin Kuwau, 2 MLJ 158 (1998). Sagong Bin Tasi V Kerajaan Negeri Selangor, 2 MLJ 591 (2002). Kerajaan Negeri Selangor V Sagong Bin Tasi, 6 MLJ 289 (2005). Sangka Bin Chuka \& Ors V Pentadbir Tanah Daerah Mersing \& Ors, 7 MLJ 480 (2015). Mohamad Bin Nohing V Pejabat Tanah Dan Galian Negeri Pahang, MLJU 291. Ketua Pengarah Jabatan Hal Ehwal Ehwal Orang Asli \& Anor V Mohamad Bin Nohing (Batin Kampung Bukit Rok) \& Ors and Another Appeal, 6 MLJ 527 (2015). Yebet Bt Saman \& Ors (Sued on Behalf of Himself and 76 Other People of Semaq Beri as Listed in Appendix a) V Foong Kwai Long \& Ors, 2 MLJ 498 (2015).

Adong Bin Kuwau V Kerajaan Negeri Johor.

Superintendent of Lands \& Surveys Miri Division V Madeli Bin Salleh (2008) 2 MLJ 677, 2 MLJ 677 (2008). The court has noted that the same principle on the common law land rights of indigenous peoples applies to the Orang Asli and the Natives of Sarawak: Amit Bin Salleh V the Superintendent, Land \& Survey Department Bintulu, 7 MLJ 10 (2005).

$4 \quad$ Kerajaan Negeri Selangor V Sagong Bin Tasi.

5 Izawati Wook, "The Rights of the Orang Asli in Forests in Peninsular Malaysia: Towards Justice and Equality" (Victoria University, 2015).; Yogeswaran Subramaniam, "A Review of the Orang Asli Cases and Property Rights: An Aboriginal Title Perspective," Malayan Law Journal 7 (2007). 
refute a hypothesis, or draw conclusions on a particular subject matter. This approach may also be used to make predictions about the future. ${ }^{6}$

Drawing from historical events that shaped the current legal system in Malaysia, this article argues that the development of laws and administrative practices observed legal principles respecting local inhabitants' rights in land and resources arising from their customary practices. It provides a historical perspective of early laws and official practices in the Malay Peninsula in relation to land rights of the Orang Asli in Peninsular Malaysia. It also reveals that the laws acknowledged the distinct political and social identities of the local groups, including the Orang Asli. Consistent with the theme, there were striking similarities to British practices in other regions, including North America, India and Australia, suggesting direct influence in the Malay Peninsula. From this position, there is no legal basis to state that the Orang Asli have no legal rights to their land in which they customarily reside. It is therefore suggested that the same principle should govern both the interpretation and implementation of the laws, specifically the APA 1954 and its future direction.

\section{THE TERM 'ORANG ASLI'}

The term 'Orang Asli', Malay words which mean 'original peoples' or 'first peoples', is used to refer to the communities characterised as 'aboriginal peoples' under various legislation in Malaysia. These legislations include the Federal Constitution, ${ }^{7}$ the Aboriginal Peoples Act 1954, the National Forestry Act $1984^{8}$ and the Wildlife Conservation Act 2010. ${ }^{9}$ The term Orang Asli is widely used in many policy statements of the executive government since the 1980s and has gained acceptance amongst the communities.

The Federal Constitution differentiates the original or local inhabitants in Malaysia into three groups i.e. Malays, aboriginal

6 Eugene M and Christine E. Lynn, "Research Method in the Social Science: Historical Designs," Lynn University, http://lynnlibrary.libguides.com/c.php?g=549455\&p=3771806.

7 Article 8(5)(c); Article 45(2); Ninth Schedule Federal List Item 16, Federal Constitution.

$8 \quad$ Ss 40(3), 62(2)(b), "National Forestry Act 1984 (Malaysia). "

9 S 51(1), Wildlife Conservation Act 2010. 
peoples and natives. The word 'Malay' refers to the majority Malays, loosely defined as a 'person who professes the religion of Islam, habitually speaks the Malay language and conforms to Malay customs'. ${ }^{10}$ Meanwhile the word 'aborigines' refers to an 'aborigine of the Malay Peninsula.' 'Native' on the other hand, specifically refers to a person belonging to the ethnic communities in Sabah and Sarawak specified under Art 161A(6) of the constitution.

Under the Aboriginal Peoples Act 1954, the specific legislation that governs the affairs of the Orang Asli, the aboriginal peoples are defined by characteristics including language, way of life, custom and belief as well as lineage or blood relation to the aborigines. ${ }^{11}$ An aboriginal ethnic group is defined as 'a distinct tribal division of aborigines as characterised by culture, language or social organisation ...'. It may also include any group that is declared by the state authority as such. ${ }^{12}$ An aboriginal community is defined as 'members of one aboriginal ethnic group living together in one place'. ${ }^{13}$

There are 3 groups of the Orang Asli which are classified for administrative purposes, namely, Negrito, Senoi and Proto-Malay. These three groups actually represent a further division of 18 tribes of diverse characteristics physically, socially and culturally. ${ }^{14}$ They are minorities in the peninsula which number is less than $0.5 \%$ of the Malaysian population. ${ }^{15}$

\section{HISTORICAL DEVELOPMENT OF LAW AND OFFICIAL PRACTICE IN THE MALAY PENINSULA}

This section explores British practice in the Malay Peninsula, as well as its origin and background. It suggests that the law and policy of the

Art 160(2), Federal Constitution.

S 3, Aboriginal Peoples Act 1954.

S 2, ibid.

S 2 ibid.

14 For a detailed account on the population, see, eg, Iskandar Carey, Orang Asli:

The Aboriginal Tribes of Peninsular Malaysia (Kuala Lumpur: Oxford University Press, 1976). Robert Knox Dentan et al., Malaysia and the Original People: A Case Study of the Impact of Development on Indigenous Peoples (Boston: Allyn and Bacon, 1997).

15 Human Rights Commission of Malaysia (Suhakam), "Report of the National Inquiry into the Land Rights of Indigenous Peoples", (Kuala Lumpur: Suhakam, 2013). 
Malay states relating to land and resources are based on the practice of respect to and acknowledgement of the rights of peoples, including the Orang Asli, derived from their law and custom. This was a longenduring practice which developed into a significant principle underlying the development of law at present and its interpretation.

\section{Colonisation, Treaty-Making and Treatment of Local Custom}

British practices during the colonisation of North America may have laid the foundation for the development of the doctrine of native title in the common law jurisdictions including Malaysia. Subsequent to the loss of British America upon the establishment of the United States in 1776, the British expanded its political territory to Asia, the Pacific and Africa. During this colonisation period, the imperial practice recognised the political autonomy of indigenous peoples; this was later developed into a body of political practices and common law. ${ }^{16}$

Treaty making became the official policy of the British crown in acquiring land from Indian nations in North America, not only in terms of law and morality but also serving as an integral strategy for pragmatic reasons, mainly for business and trading expansion. A treaty demonstrated the recognition of the local inhabitants or the indigenous peoples as legal and political entities with rights to sovereignty and political authority over their respective lands. ${ }^{17}$ Such treaties defined the relationship between the British crown and indigenous peoples. The terms of the treaties certainly varied depending on the circumstances of particular territories, but the common principle was that the indigenous peoples did not lose their rights to land and their resources after being subjected to British sovereignty; they maintained a right to some form of political representation in relation to the powers of the new state. ${ }^{18}$

The North American experience heavily influenced the development of legal principles and policy in the independent United

\footnotetext{
16 James W. Zion and Robert Yazzie, "Indigenous Law in the Wake of Conquest," Boston College International Comparative Law 20 (1997).

17 Douglas R Francis, Richard Jones, and Donald B Smith, Origins: Canadian History to Confederation (Nelson Education Ltd, 2009).

18 Tom G. Svensson, "On Customary Law: Inquiry into an Indigenous Rights Issue”, Borialia, Acta 20, no. 2 (2003).
} 
States of America, ${ }^{19}$ Canada and other territories. In the US, these early experiences developed into laws protecting the sovereignty of the Native American nations, imposing fiduciary obligations on the US government to protect their property. ${ }^{20}$ In Canada, this treatymaking practice led to the recognition of First Nation's property rights in common law, which also received constitutional protection. ${ }^{21}$ Treaty-making spread to other parts of the world including New Zealand and some parts of British Columbia. It was also used in Africa and Asia, particularly in India and the Malay States. ${ }^{22}$

State practices respecting the rights of existing inhabitants formed the basis for the development of the doctrine of aboriginal title as endorsed by courts in common law jurisdictions. It was also acknowledged by the International Court of Justice in $1975 .{ }^{23}$ British practice was not unique, as the same broad pattern was also seen in treaty-making between other European powers and respective indigenous peoples during the colonisation period. ${ }^{24}$ Despite many flaws and breaches in practice, this tradition has become an important source of precedent in countries with substantial indigenous groups. ${ }^{25}$

In India and East Asia, relations with the British began as trade in the $17^{\text {th }}$ century through the British East India Company (BEIC). This

19 In 1783, the Great Britain ceded the territory to the United States through the Treaty of Paris. Zion and Yazzie, "Indigenous Law in the Wake of Conquest." Zion \& Yazzie, 66-67.

21 Brian Slattery, "The Hidden Constitution: Aboriginal Rights in Canada," American Journal of Comparative Law 32 (1984). The Royal Proclamation of 1763 is mentioned in s 25 of the Canadian Charter of Rights and Freedom.

22 See P.G. McHugh, Aboriginal Title: The Modern Jurisprudence of Tribal Land Rights (Oxford: Oxford University Press, 2011).

23 Western Sahara, Advisory Opinion of 16 October 1975, 12 (1975). The majority state that:

"Whatever differences of opinion there may have been among jurists, the State practice of the relevant period indicates that territories inhabited by tribes or peoples having a social and political organization were not regarded as terra nullius. It shows that in the case of such territories the acquisition of sovereignty was not generally considered as effected unilaterally through 'occupation' of terra nullius by original title but through agreements concluded with local rulers."

24 SJ Anaya, Indigenous Peoples in International Law, Second ed. (Oxford: Oxford University Press, 2004).

25 Audun Sandberg, "Collective Rights in a Modernizing North - on Institutionalizing Sámi and Local Rights to Land and Water in Northern Norway," International Journal of the Common 2, no. 2 (2008). 
company expanded to bring a large swath of the region under its dominion by 1773 with Calcutta as its capital. The Indian Empire later was comprised of British India, which was under direct imperial rule $;^{26}$ over 600 princely states, which were either protectorates or protected states and other territories not formally included in the Indian Empire such as Bhutan, Nepal, Afghanistan, Arabia, and Somalia. $^{27}$

The BEIC in the beginning was firmly opposed to conquest as a way of expansion. ${ }^{28}$ Its relationship with the territories in Asia was established through a series of treaties with the local rulers to whom rent or tribute was usually paid. These treaties defined the relationship with local rulers, while the extent of British powers in the territories varied. ${ }^{29}$ British settlements in India, Madras and Calcutta were acquired by treaty. Mumbai was ceded by the Portuguese in $1661 .^{30}$ By the mid-1700s, however, it expanded the territories it occupied in India while continuing its indirect rule through treaty arrangements with local princes.

The British developed a system of Residents, who worked as advisors to local rulers, which originated from the BEIC practice in the $18^{\text {th }}$ century. ${ }^{31}$ Under that system, all of the states and territories, other than British India (which was directly under British rule as a result of conquest or cession), whether independent or under British protection, were incorporated into a vast diplomatic network controlled by the government of the Indian Empire. Each had its own ruler or chief overseen by a British Resident or agent. These

26 British India consisted of seven to seventeen colonial provinces during 1858 1947, each headed by a British governor, lieutenant-governor, or chief commissioner: James Onley, "The Raj Reconsidered: British India's Informal Empire and Spheres of Influence in Asia and Africa," Asian Affairs XL, no. 1 (2009).

27 Ibid.

28 Anthony Pagden, "The Struggle for Legitimacy and the Image of Empire in the Atlantic to C. 1700," in The Origins of Empire: British Overseas Enterprise to the Close of the Seventeenth Century, ed. Alain M. Low and Nicholas P. Canny (2001).

29 Onley, "The Raj Reconsidered: British India's Informal Empire and Spheres of Influence in Asia and Africa."

30 Pagden, "The Struggle for Legitimacy and the Image of Empire in the Atlantic to C. 1700."

31 For history on the origin of the Resident system, see: Onley, "The Raj Reconsidered: British India's Informal Empire and Spheres of Influence in Asia and Africa." 
residencies and agencies were run by the Indian Political Service (IPS). Originally, Residents took their orders from the headquarters of one of the Company's three Presidencies in India. ${ }^{32}$

By 1824, the Indian Empire also comprised the territories of Penang, Malacca and Singapore in the Malay Peninsula which formed the Straits Settlements in 1826. The Straits Settlements were originally part of the territory under control of the BEIC from Calcutta. They came under direct British control as crown colonies in 1867 when their affairs were shifted to the Colonial Office in London. In 1858 at the end of the Indian Mutiny and the removal of the last Mughal Emperor, the British government assumed direct control. ${ }^{33}$

In the Malay states, direct British influence in the administration began only in the late nineteenth century with the signing of the Treaty of Pangkor in 1874. Following this, the first British Resident was appointed in Perak. Similar to the system practiced in the Indian Empire, the duty of the Resident was to advise the Malay ruler specifically in the matter of revenues and the general administration of the state. This marked the beginning of the Resident System in Perak and became precedent to the introduction of the same system in other states in the Malay Peninsula. Although there were many other treaties signed between the Malay rulers and the British representatives prior to the Pangkor Treaty, they were made only for trade purposes. ${ }^{34}$

In the same year, British officers were also sent to Selangor to assist the Sultan in the state's administration. Although there was no treaty signed for the appointments of the British officers in Selangor, Roland Braddell wrote that an interchange of letters, a proclamation, and the reception of officers were to assist the Sultan to 'govern his country and to protect the lives and property of dwellers in, and traders to, Selangor'. ${ }^{35}$ These became the general reasons for the

32 The headquarters were established in Surat (1616-1877), later Bombay Castle in Bombay; Fort St George in Madras (established 1653); and Fort William in Calcutta, Bengal (established 1698); Ibid., 45.

33 Ibid, 50.

34 Eg., Treaty with the East Indian Company 1825, Cession of Dinding 1826, Treaty with the East India Company 1826.

35 Roland Braddell, The Legal Status of the Malay States (Kuala Lumpur: MPH, 1931), 6. The extract was reproduced in Salleh Buang, "Malay Customary Tenure: A Brief Historical Survey," in The Centenary of the Torrens System in Malaysia, ed. Ahmad Ibrahim and Judith Sihombing (Kuala Lumpur: Malayan Law Journal, 1989), 171. 
reception of the British officials and their power in the Malay States. In each of the other states in the Malay Peninsula, treaties were also made with respective local authorities to define their relationship. ${ }^{36}$

In most cases, the British Residents handled the external affairs and the defence of the Malay states, whilst the states continued to hold responsibility for internal domestic matters. By the mid- $19^{\text {th }}$ century, Residents became colonial administrators in states where the British assumed direct control i.e. Perak, Selangor, Pahang and Negeri Sembilan which in 1895 formed a federation known as the Federated Malay States. In other states indirectly controlled by the British, British officers generally acted as diplomatic officers controlling external affairs, while British influence in internal affairs was also substantial in many states.

\section{British Practice in the Malay Peninsula and Local Customs: Early Perspective}

During the colonial period, the local inhabitants in the Malay states were largely governed by their own laws and custom. ${ }^{37}$ In the Malay Peninsula, the Portuguese and Dutch left the administration of justice among their non-Christian Asian subjects in the hands of their political leaders. The Dutch practice in Java was to leave the natives to their own custom and laws unless they clashed with what the Dutch regarded as accepted principles of justice. Buss-Tjen suggests that this was also the case in Malacca. ${ }^{38}$ Maxwell also had the same view, that in 1825 when Malacca was taken by the British, the land tenure in Malacca was governed by Malay customary tenure, unchanged by previous rulers. ${ }^{39}$

The British introduced a range of new laws in the region ${ }^{40}$ but also maintained existing rights and interests of the inhabitants, their

36 Negeri Sembilan: Treaty of 1889; Pahang: Treaty of 1887; Kedah: Treaty of 1791, Third Treaty of 1800; Kelantan: Treaty with Great Britain 1910; Johor: Treaty of 1885, Treaty of 1914 (Amendment of 1885 Treaty).

37 Gordon P. Means, Malaysian Politics, Second ed. (London: Hodder and Stoughton, 1976), 43.

38 P.P. Buss-Tjen, "Malay Law," The American Journal of Comparative Law 7, no. 2 (1958), 253.

39 W E Maxwell, "The Laws and Customs of the Malays with Reference to the Tenure of Land," JSBRAS (1884).

40 The First Charter of Justice introduced the common law of England to Penang in 1807, and the Second Charter of Justice introduced the common law to Malacca 
local custom and religions. In providing for the common law to be the basis of the legal system in the Crown colonies, local laws and custom were not intended to be abrogated. The same could also be traced to the British policy in the Indian Empire, in which they demonstrated interest and sensitivities to the existence and practice of Hindu and Islamic law. Local laws were referred to in the courts established since the EIC's rule. ${ }^{41}$ English law newly introduced to the land was applied only to Indians who had no other applicable body of law such as Armenians and Parsis. ${ }^{42}$ Local customary laws were compiled and judicial institutions were established for different multicultural communities. ${ }^{43}$

\section{The Straits Settlements}

In Penang, the introduction of laws was mainly intended to solve the problem of legal chaos due to the absence of laws applicable to British subjects, which had led to injustice among local inhabitants. ${ }^{44}$ For example, in Regina $v$ Willans, ${ }^{45}$ Maxwell, R. observed that the First Charter of Justice 1807 respected native religions and usages and that the law in Penang before 1807 was the personal law of the local people. Cases, he felt, should be decided by the principles of natural law and equity which he said, in the case of British subjects, was English law. Nevertheless, many judges found that English law was applicable to local subjects as they erroneously believed that there was no existing legal system in Penang before the grant of the First Charter of Justice. The judges in the cases of Yeap Cheah Neo $v$ Ong Cheng $\mathrm{NeO}^{46}$ and Fatimah v D $\operatorname{Logan}^{47}$ for instance, ruled that

and Singapore in 1826. Another granted to the Straits Settlements was Charter of Justice 1855.

41 John F. Riddick, History of British India: A Chronology (Greenwood Publishing Group, 2006) , 184.

42 Ibid., 193. An example was the Lex Loci Act which was enacted in 1845.

43 Ibid., 184-96.

44 Kamoo $v$ Thomas Turner Bassett, 1 Ky 1 (1808). Stanley R held that the application of English law to the case which facts happened before the grant of the 1807 Charter is consistent with its objective to protect persons, liberties and properties of the natives from oppression and injustice inflicted by the British subjects.

$45 \quad$ Regina $v$ Willans, 316 (1858).

46 (1885) LR 6 PC 381; 1 Ky 326.

$47 \quad$ (1871) 1 Ky 255. 
Penang was wholly uninhabited at the time of Captain Light's occupation in 1789, "no trace of any laws having been established" and thus all settled in Penang became the subject of English law.

On the other hand, Sir Benson Maxwell in the Willans' case $^{48}$ expressed doubt that the English law can be made lex loci by Captain Light and his companies which "were a mere garrison." Furthermore, British records also evidenced an organised settlement in Penang prior to the coming of the British. ${ }^{49}$ Logan in 1850 also wrote that Malay Muslims such as Tengku Syed Hussain and their families who lived in Penang were governed by their own custom and were not subjected to the English laws. ${ }^{50}$

Drawn from the context of classification of a region, ceded or settled under the law of the nation at that time, absence of inhabitation was considered to justify the application of the discoverer's law on the land. On this presumption, Buss-Tjen suggested that the British approach in introducing new laws, incidentally, was contrary to the practice of Dutch colonisation which left the native populations to their own laws and customs unless they clashed with principles of justice and equity. He suggested that this difference is the cause of the different valuation of and approach to native adat law by the two colonising powers. ${ }^{51}$ Nonetheless, this view did not take into account the fact that the concept of rule over territory came into practice only in the late $19^{\text {th }}$ century. In reality, the laws introduced to Penang through the 1807 Charter of Justice were intended to be applicable to English subjects only.

The same practice of respect for the local customs and existing rights was also seen in Singapore and Malacca. As mentioned in Yeap

48 (1858) 3 Ky 16,

50 Logan, J. R. (peny.)1850. "Notices of Pinang", JIA, (4), at 655 cited in Mahani Musa, "Keterlibatan Orang Melayu-Muslim Dalam Persatuan Sulit Di Pulau Pinang Sejak Abad Ke-19 (Involvement of Malay-Muslims in Secret Societies in Penang since 19th Century)" (paper presented at the Pengkisahan Melayu Pulau Pinang, Penang, 2001).

50 Logan, J. R. (peny.)1850. "Notices of Pinang", JIA, (4), at 655 cited in Mahani Musa, "Keterlibatan Orang Melayu-Muslim Dalam Persatuan Sulit Di Pulau Pinang Sejak Abad Ke-19 (Involvement of Malay-Muslims in Secret Societies in Penang since 19th Century)" (paper presented at the Pengkisahan Melayu Pulau Pinang, Penang, 2001).

51 Musa, "Keterlibatan Orang Melayu-Muslim Dalam Persatuan Sulit Di Pulau Pinang Sejak Abad Ke-19 (Involvement of Malay-Muslims in Secret Societies in Penang since 19th Century)", 255. 
Cheah Neoh v Ong Cheng Neo, ${ }^{52}$ the Charter of 1826, this introduced English law to the region, provided that the Court of the Colony was to exercise jurisdiction as an Ecclesiastical Court in so far as the religions, manners and custom of the inhabitants will admit. ${ }^{53}$ In Malacca, ceded by the Dutch to the British, ${ }^{54}$ lands under Dutch grants were converted to English fee simple in 1839. The lands of the interior continued to be governed by local customary law which recognised private ownership of land by right of occupation and capability of being inherited. ${ }^{55}$ This customary tenure protected both, the owner and his sub-tenant cultivator. ${ }^{56}$

Although the English Deeds System was implemented to replace the former system of title including the customary law, the land rights held under customary land tenure continued. The English Deeds System was implemented gradually until fully in 1886. Among efforts made to recognise the customary lands except in Naning was Malacca Lands Customary Rights No. IX of 1886 (Ordinance 1886). The 1886 Ordinance was replaced by the National Land Code (Penang and Malacca Titles) $1963^{57}$ extending the Torrens system to replace the Deeds System formerly in practice. The customary land in Naning, a district in Malacca, continued to be governed by Adat Perpatih up to the present day.

Malkin, R. in In the Goods of Abdullah ${ }^{58}$ emphasised the significance of applying the local laws practiced by different local people in Malacca:

52 (1872) 1 Ky. 326 PC.

53 See also, Isaac Penhas V Tan Soo Eng, MLJ 73 (1953), PC: The common law of England was in force in Singapore in 1937 except in so far as it was necessary to modify it to prevent hardships upon the local inhabitants who were entitled by the terms of the Charters of Justice to exercise their own respective religious customs and practices.

54 Malacca was ceded by the Dutch to British through Anglo-Dutch Treaty of 1824.

55 Sahrip V Mitchell, Leic 466 (1879).: Sir Benson Maxwell CJ held that:

"The Portuguese, while they held Malacca and after them, the Dutch, left the Malay custom or lex non scripta in force. That was in force when this Settlement was ceded to the Crown appears to be beyond dispute, and that the cession left the law unaltered is equally plain on general principles ... Further, the custom has always been recognized by the Government; ... The Malacca Land Act 1861 plainly refers to and recognizes the same customary tenure."

56 Claridge R, Abdul Latif V Mohamed Meera Lebe, 4 Ky 249 (1829)..

57 Act 518 (in force in $1^{\text {st }}$ January 1966).

$58 \quad$ (1835) 2 Ky Ec 8. 
I believe it would be very difficult to prove the existence of any definite system of law applying to Prince of Wales' Island or Province Wellesley previous to their occupation by the English; but that law, whatever it was, would be the only law entitled to the same consideration as the Dutch law at Malacca; indeed, even that would not in general policy, though it might in strict legal argument; for there might be much hardship in depriving the settled inhabitants of Malacca of a system which they had long understood and enjoyed ... any man therefore who wishes his possessions to devolve according to the Mohamedan, Chinese, or other law, has only to make his Will to that effect, and the Court will be bound to ascertain that law and apply it for him.

Increasingly in the $19^{\text {th }}$ century, the British tended to apply English law, but existing local personal laws were continued. This is evident by the recognition and continuance of local institutions alien to English law. For instance, Muslim laws in matrimonial matters, intestacy and succession were recognised ${ }^{59}$ and polygamy amongst Chinese was acknowledged by the court. ${ }^{60}$

\section{Introduction of English Laws in the Malay States and the Position of Local Customs}

The Malay states were legally sovereign and independent. Perak, Selangor, Negeri Sembilan and Pahang were under direct rule of the British with a Resident appointed to assist in the States' administration. In 1895, the four states were confederated into the Federated Malay States which lasted until the establishment of the Federation of Malaya in 1946. The other Malay states were indirectly ruled by the British through a British Advisor.

In these states, British administrators applied the practices and customary laws of the inhabitants as they understood them. Minatur suggested that custom and practices of the locals were viewed by the British as the common law of the people in those spheres of lives to which it applied. ${ }^{61}$ Although some customary laws were coded into

\footnotetext{
59 Ordinance No. V of 1880 and its amendments, an amendment in 1923 (No. 26 of 1923)

$60 \quad$ Six Widows Case 12 Sslr 120, 12120 (1908).

61 Joseph Minatur, "The Nature of Malay Customary Law", Malaya Law Review 6 , no. 2 (1964).
} 
writing, ${ }^{62}$ the exact content of the laws was often in doubt as numerous customary laws were in fact unwritten, vary in different districts and changed gradually through local judicial procedures. ${ }^{63}$ Hooker pointed out that there is a probability that the contents of the written codes were never applied as legal rules. ${ }^{64}$

Legislation was introduced in matters thought not to be provided for in local laws. In other areas, legislation was introduced to replace local laws in pursuit of 'better' justice. For instance, adat on criminal law was replaced by a Penal Code based on the Indian Penal Code, and a Criminal Procedure Code. Evidence laws were introduced in the belief that it is more favourable to a suspect and in consonance with principle of natural justice. ${ }^{65}$

In the absence of local laws, reference to the common law and equity of England was provided by civil law enactments. ${ }^{66}$ However, the legislations require that the application of the English law is subject to consideration of, and consistency with, the local circumstances. Although it had been the practice of judges to refer to and apply the English common law and equity before the enactment of the legislation, ${ }^{67}$ that was regarded as an exception to the general rule. In some cases, the judges found no recognisable laws, although such findings may have been erroneous. In some other cases, local custom was thought to be unreasonable, unjust and against public policy. ${ }^{68}$ As Terrel Acting CJ sought to explain in Motor Emporium v Arumugam, ${ }^{69}$ on many occasions the courts acted on equitable

62 Examples were Malacca Laws 1523, Pahang Laws 1596, Kedah Laws 1605, Johor Laws 1789, Minangkabau Digests, Perak Code and the Ninety-Nine Laws of Perak 1765.

M. B. Hooker, "The Interaction of Legislation and Customary Law in a Malay State," The American Journal of Comparative Law 16, no. 3 (1968).

"The Challenge of Malay Adat Law in the Realm of Comparative Law," International and Comparative Law Quarterly 22 (1973), 497.

65 Buss-Tjen, "Malay Law", 258. He stated that local custom on law of evidence such as declaring an accused person guilty just because of "rumours spread by flies" or because the man did not stop to ask for betel, was considered as unjust and unreasonable.

Civil Law Enactment 1937 (Federated Malay States). The provision was extended to other Malay states in 1951 and to the whole Federation in 1956.

67 Government of Perak v Ar Adams, 2 FMSLR 144 (1914). (tort action); BussTjen, "Malay Law", 256.

68 In Re the Will of Yap Kwan Seng, Deceased, 4 FMSLR (1924).- a trust for ancestral worship was held as not for public religious or charitable use and infringe the rule against perpetuities.

Motor Emporium v Arumugam, MLJ 276 (1933). 
principles, not because English rules of equity applied but because such rules happen to conform to the principles of natural justice.

In similar tone, Lord Scarman in Jamil bin Harun $v$ Yang Kamsiah wrote: ${ }^{70}$

... it is for the courts of Malaysia to decide, subject always to the statute law of the Federation, whether to follow English case law. Modern English law may be persuasive, but are not binding. In determining whether to accept their guidance the courts will have regard to the circumstances of the States of Malaysia and will be careful to apply them only to the extent that the written law permits and no further than in their view it is just to do so. The Federal Court is well placed to decide whether and to what extent the guidance of modern English authority should be accepted.

However, in effect, extensive laws based on English principles were gradually introduced. One reason was the difficulty in determining the exact local custom. This difficulty was noted by many writers who researched customary law in the region. ${ }^{71}$ Although there were some digests of law, including the Laws of Malacca and the NinetyNine Laws of Perak, the enforceability of the written laws was dubious. Furthermore, some qadis of districts (judges administering Islamic law) who were often called upon to clarify the customs of the locals were not really familiar with exact adat in practice but instead gave the content of Islamic law that they knew but not in practice locally. Some qadis with an educational background from the Middle East countries were resistant towards customs as practiced by the local people. Although local custom is accepted by Islamic law as a source of law, the qadhis took a narrow approach towards Islam and regarded local customs as un-Islamic, thus imposing their view upon the local people concerning the laws which were supposed to regulate them.

Another reason leading to the introduction of foreign laws was the Eurocentric perspective of English-trained lawyers who were influenced by the 'stadial' or stepped view of civilisation. Together with the notions of 'progress', 'less civilised' peoples had the

[1984] 1 MLJ 217.

Buss-Tjen, "Malay Law" ; M. B. Hooker, "The Interaction of Legislation and Customary Law in a Malay State". 
potential to ascend the grades or steps towards civilisation. ${ }^{72}$ This belief was used to justify colonisation in the 17 th and $18^{\text {th }}$ centuries and shaped their perspectives towards the status of the local people and the standard of their laws. The moral imperative of 'the white man's burden' reflected a belief that Christian nations should guide less civilised societies to enlightenment. ${ }^{73}$ The same perspectives were also reflected in other regions such as Australia and New Zealand. $^{74}$

\section{LAND AND FORESTRY LEGISLATION AND THE EXISTING RIGHTS}

The policy and practice to respect the interests of the existing inhabitants have also been imprinted in various legislations governing the administration of land, customary land and forests. There is nothing in the legislation that introduced the Torrens system in the Malay states that denied the existing local rights. As spelled out in Sahrip $v$ Mitchel, ${ }^{75}$ failure to take out the proper title for occupied land under the relevant legislation ${ }^{76}$ did not make the occupier liable for ejectment. Similarly, in Roberts @ Kamarulzaman v Ummi Kalthom,${ }^{77}$ provisions of the Land Code with regard to indefeasibility of title of registered land did not affect entitlements under Malay customary law in matters of 'jointly acquired property'. Besides, legislation providing for reserves of forests and sanctuary calling, by

72 Nathaniel Wolloch, "The Civilizing Process, Nature, and Stadial Theory" Eighteenth-Century Studies 44, no. 2 (2011).

73 Charles Hirschman, "The Making of Race in Colonial Malaya: Political Economy and Racial Ideology, " Sociological Forum 1, no. 2 (1986).; Daniel P. S. Goh, "Imperialism and 'Medieval' Natives: The Malay Image in AngloAmerican Travelogues and Colonialism in Malaya and the Philippines", International Journal of Cultural Studies 10 (2007).; S.H. Alatas, The Myth of the Lazy Native: A Study of the Image of the Malays, Filipinos and Javanese from the 16th to the 20th Century and Its Function in the Ideology of Colonial Capitalism (London: Frank Cass, 1977).

74 Tara Ward, "The Right to Free, Prior and Informed Consent: Indigenous Peoples' Participation Rights within International Law" Northwestern Journal of International Human Rights 10, no. 2 (2011) , 486.

75 (1870) Leic, 466 Sir P. Benson Maxwell CJ.

76 Act XVI of 1839 (Malacca).

77 Roberts@ Kamarulzaman v Ummi Kalthom, 1 MLJ 163 (1963). 
notice, for any claims of interests in the proposed reserve reflects the same policy.

However, the legislation regulating land administration in particular was introduced under presumption that the locals had no ownership rights in the soil but a mere usufruct under local custom. Maxwell compared this to English law:

No subject in a Malay state can lawfully claim to hold any property in land approaching (the English) freehold or fee simple tenure. ${ }^{78}$

In drafting legislation for land administration in the Malay states, Maxwell made the Sultan the owner of lands in his state. David Wong refuted this claim, pointing out that none of the old Malay digests contained a statement that the Sultan was the owner of lands in his state. ${ }^{79}$ In similar vein, Hunud has also emphasised that:

... the fact that the Malay ruler used to issue grants to chiefs or royal favourites did not seem to implicate that the ownership of the soil was in fact divested of him. It never meant either that the tenant's right was interfered with. Most importantly, the exercise neither meant to establish any tenurial or feudalistic relationship between the grantee and the original occupant of the land, nor could it establish the existence of any of such relationship between the peasant and the raja himself. ${ }^{80}$

Kratoska also pointed out that the pre-colonial land tenure in the Malay Peninsula was imperfectly understood by the British. Adat or custom legal codes indicated that peasants enjoyed security of tenure

78 Maxwell, "The Laws and Customs of the Malays with Reference to the Tenure of Land ", 1122.

79 David SY Wong, Tenure and Land Dealings in the Malay States, Singapore University Press (1975), 16. David Wong points out that Perak Code states that the forests belonged to no man. See also The Laws of Melaka (Undang-undang Melaka). It contains no provision about the ownership of land by Ruler or Sultan. S 20.1 provides:

"With regard to 'dead land', nobody has property rights to it, (when) there is no sign of its being under cultivation by someone, then certainly nobody can lay a claim to that land. If someone cultivates it into (a rice-field, be it) a huma or ladang or sawah or bendang, no one can proceed against him. That is what is understood by dead 'land'." (Liaw Yock Fang, Undang-undang Melaka [The Laws of Melaka], Bibliotheca Indonesica (Koninklijk Instituut, 1976), 110-1).

80 Hunud Abia Kadouf, "The Traditional Malay Ruler and the Land: Maxwell's Theory Revisited," Malayan Law Journal 1 (1997). 
so long as their lands remained under cultivation. ${ }^{81}$ While the British version was based largely on statements made to various officials and not on the evidence of particular instances where such occurrences took place, and without further empirical evidence the question of whether and under what circumstances the aristocracy could override customary prescriptions cannot be answered. ${ }^{82}$

\section{THE LAND OF THE ORANG ASLI}

Some accounts suggest that the Malay rulers often regarded themselves as superior to the aborigines, and they gave the Orang Asli letters of authority as delegation of political powers for the leaders of the Orang Asli groups to administer the people and the territory under their reigns. ${ }^{83}$

In contrast to this view, many have also emphasised that the Orang Asli in fact had their own political establishments with their own leaders and legal systems within particular territories. Their leaders, who were the reference point for all customary matters, were regarded as having the same standing as that of the Malay rulers. ${ }^{84}$ The fact of the matter was that the relationships with the Malay sovereign were mere political alliances. Some groups played important roles in the defence of some Malay rulers as allies but were not subject of the rulers.

Furthermore, there are many traditional stories suggesting that marriage with the Orang Asli legitimised Malay connection with, and political power over, their territories. ${ }^{85}$ The Orang Asli also had

81 Paul H. Kratoska, "The Peripatetic Peasant and Land Tenure in British Malaya" Journal of Southeast Asian Studies 16, no. 1 (1985). Ibid.

83 Hamimah Hamzah, Rights and Interests in Land among the Orang Asli in Pahang: Orang Asli and Customary Land Rights (LAMBERT Academic Publishing 2012).

84 Colin Nicholas, The Orang Asli and the Contest for Resources (Copenhagen: International Work Group for Indigenous Affairs, 2000), 75 citing Endang, an Orang Asli leader in Pahang with reference to an oral tradition of Batin Simpok and Batin Simpai in Pahang.

85 Eg of the legends: Haji Buyong Adil, Sejarah Negeri Sembilan (Dewan Bahasa dan Pustaka, 1981), 4 on inter-marriage of a Sultan of Johor with a Biduanda from Negeri Sembilan; Maxwell, WE, 'The History of Perak from Native Sources' (1882) 8 Journal of the Straits Branch of the Royal Asiatic Society 93125 on the legend of the White Semang in Perak, a member of whom married a 
trading relationships with the Malays particularly in the supply of forest resources in exchange for other needs. ${ }^{86}$ Likewise, custom in Negeri Sembilan or locally known as Adat ${ }^{87}$ Perpatih, specifically recognised that the aborigines owned the forests and its resources and required Malays to respect their needs and interests. ${ }^{88}$

Therefore, there is ample evidence to show that the autonomy and control of the aborigines over their own territories were not denied. The aborigines regarded themselves as the original inhabitants of the territories that they lived in, independent of the Malay rulers. ${ }^{89}$

Nakhoda Kasim from Johor and founded the Perak Sultanate; Gullick, JM, Indigenous Political Systems of Western Malaya (1965) 17 (The Athlone Press, 1965), 39 on how aspiring heirs in Negeri Sembilan had to resort to claiming Orang Asli (matrilineal) ancestry in order to be eligible for hereditary positions. This was achieved by claiming that the founders of their families were the sons of Orang Asli ancestresses married to Malaccan noblemen. The works are cited in ibid., 75.

John D. Leary, "Orang Asli Contacts with the Malays, Portuguese and Dutch in Peninsular Malaya from 1400 to 1700," Asian Studies Review 18, no. 2 (1994), 98.

'Adat' is the Malay word for custom.

88 Hooker, MB, Readings in Malay Adat Laws (Singapore University Press, 1970), 25-6 cited in Nicholas, The Orang Asli and the Contest for Resources, 74. Ibid., 74-6 citing various works including: Andaya, Barbara Watson and Andaya Y Andaya, A History of Malaysia (Macmillan Education, 1982) 49-50: suggest that when the Malay newcomers arrived with an established system and political ranks, there were already Orang Asli groups in the Malacca region. When Parameswara, the founder of the Malacca Empire, arrived in Malacca, there were populations including the Orang Asli living in the region. Parameswara tightened his position by building relationships with the communities, enjoining them in the political establishment or through inter-marriage; Mikhulo-Maclay, N Von, 'Ethnological Excursions in the Malay Peninsula: Nov. 1874 to Oct. 1875: (Preliminary Communication)' (1878) 2 (Dec) Journal of the Straits Branch of the Royal Asiatic Society, 203-221, 215: recorded that 'the Orang Sakai and the Orang Semang consider themselves the original inhabitants and independent of the Malay Rajahs, and so they are in fact in their woods'; Noone, H D, 'Report on the Settlements and Welfare of the Ple-Temiar Senoi of the Perak-Kelantan Watershed' (1936) 19(1) Journal of the Federated Malay States Museums 1, 61-2: observed that the Temiar people prior to the intervention of British rule 'pursued the independent existence of a hill people on the Main Range'; AH Hill, The Hikayat Abdullah: The Autobiography of Abdullah bin Kadir (1797-1854) (An Annotated Translation) Second Impression, (Oxford University Press, 1985) 260-1: the Orang Asli tribes in Naning held dominion over Naning in Malacca since early Portuguese control of Malacca. It also relates that in 1642, a representative from the Biduanda tribes was appointed as ruler in Naning during the Dutch rule in Malacca; Wilkinson, RJ 'Malay Law in Papers on Malay Subjects, Part I, 1-45', 1908 reprinted in MB Hooker (ed), 
In the same way, under British administration, the Orang Asli communities were also regarded as distinct communities from the Malays, having autonomy and control over their own territories with their own customs and traditions regulating their own affairs. The laws and policies relating to land administration also acknowledged that the aboriginal peoples had rights and interests to the lands and territories on which they lived in, distinct from those of the Malays. This is evident by various British records which indicate that certain territories belonged to the Orang Asli. ${ }^{90}$ For example, in 1861, a British colonial officer refused an application of land located in Ulu Sungei Langat up to the Pahang border by one Jaafar on the grounds that rights to the area were recognised as belonging to a local Orang Asli group. ${ }^{91}$

Juli had also pointed out that prior to independence, Orang Asli areas were marked on land register maps. ${ }^{92}$ The initiative to mark Senoi ${ }^{93}$ areas in Perak were taken by HD Noone, the ethnographer of Taiping Museum in early $20^{\text {th }}$ century. The Senoi areas were marked as 'Sakai Ladang' or 'Sakai Reserve', together with the name of the penghulu (head of community) of each of these areas.

However, the land recognised as the 'country of the Sakai ${ }^{94}$ was purposely not included in the general land registration system introduced by the British in the early $20^{\text {th }}$ century. In the year of 1900 , the Resident-General of the Federated Malay States ruled that there

Readings in Malay Adat Laws (Singapore University Press, 1970): the Biduanda tribes were also regarded as having control of their territories; Newbold, TJ, Political and Statistical Account of the British Settlements in the Straits of Malacca 2 Volumes 1839, (Oxford University Press, 1971 - reprint), Vol II 117126: relates that Jakuns and Biduandas were the respected leaders in Malacca. See, eg, David Radcliffe, "The Peopling of Ulu Langat," Indonesia 8 (1969).. Ibid., 170.

Juli Edo, "Claiming Our Ancestors' Land: An Ethnohistorical Study of Seng-Oi Land Rights in Perak, Malaysia" (Australian National University, 1998) , 314. Juli states:

"Subsequently, all marks indicating Seng-oi [Senoi] areas were erased from the new map reproduced by the independent Malaysian government, leaving no Seng-oi land on the map. This then became a major problem when the state based land transactions solely on the map without considering its reality on the ground. As a result, most of the Seng-oi areas were approved to other parties, the majority of which were state subsidiaries responsible for projects such as oil palm estates, logging, hydro-electric dams, and recently, tourism industries". Senoi is a sub-group of Orang Asli.

In the early writing about the aborigines, the word Sakai is the term normally referred to aborigines who are now grouped as Senoi. 
would be no extension to the Sakai of the system instituted for recording land titles. ${ }^{95}$ The reason was not to deny their possession but to protect the aborigines from being exploited by selling off their land for unfair consideration which would occur if they were issued formal titles. $^{96}$

Apparently, a factor considered by the British administrators in the alienation of land, in the form of grant of title, was the level of civilisation of the applicants. For example, an application for the grant of temporary occupational license to a group of aborigines was allowed as they were considered as 'civilised as any of their Malay neighbour's'. Sakai Reserve was considered as not suitable in their case. ${ }^{97}$ Compared to the Malays, the Orang Asli were regarded as inferior and for that reason required greater government control with the objective of protecting them from exploitation. This was the result of the perceived European standard of civilisation which made the distinction between the treatments of the natives. As Alice pointed out, the British conceived that the subjects of the main polities on the peninsula constituted Malays and were part of a large single community and the other tribal groups were regarded as the aborigines. ${ }^{98}$ This distinction was reinforced through policies and practices which continues up to the present day. ${ }^{99}$ It was also believed that the Orang Asli would gradually assimilate with the Malays, ${ }^{100}$ which expectedly would be treated equally under the same land registration system.

Pervasive government control practised in the Malay Peninsula over the Orang Asli was similar to the British practice in other

95 Radcliffe, "The Peopling of Ulu Langat", 172 citing Ulu Langat Land Office files 1242/00 and Selangor Secretariat files 6443/00.

96 Ibid., 172.

97 National Archive File 825/1939: Excision of a portion of land which has been planted with rubber by Sakais from the Malay Reservation in Mukim Luit, Pahang (ANM - 1957/0534944).

Alice M Nah, "(Re) Mapping Indigenous 'Race'/Place in Postcolonial Peninsular Malaysia," Human Geography 88, no. 3 (2006), 286.

99 Ibid., 286.

100 Alfred Russell Wallace in 1865, following Henry Morgan's three stages of social evolution, describes the aborigines as 'savages' and less civilized than the Mohamedan Malays. The aborigines were referred to in early writings as Semang, Sakai, Jacoon and Orang-Utan, among other names, which were derogatory indicating the general perspectives towards the people: A. R. Wallace, "On the Varieties of Man in the Malay Archipelago" Transactions of the Ethnological Society of London 3 (1865). 
jurisdictions. In Canada, the Indian Act of 1876 consolidated and imposed a system of pervasive government control over the First Peoples and their lands. In Brazil, legislation established Indians as wards of the state and set in motion government programs to manage their affairs and facilitate their adoption of Euro-Brazilian ways. The US followed the British by establishing a vast government bureaucracy to consolidate and manage its system of Indian reservations. ${ }^{101}$ This system was developed from trusteeship doctrines akin to those proposed earlier by Francisco de Vitoria as the parameters for non-consensual exercise of authority over indigenous peoples. ${ }^{102}$ Vitoria, together with Bartolomế Las Casas were Spanish jurists in the $16^{\text {th }}$ century, whose writings in defence of the rights of the indigenous peoples in Spain's American colonies were influential in shaping the imperial approach towards indigenous peoples during the colonial era. ${ }^{103}$ Their writings contributed to the development of the law of nations that regulated the conduct of states during colonisation. ${ }^{104}$ They laid the foundation of legal tradition of recognition of indigenous rights. ${ }^{105}$

As for the Orang Asli, the first and only federal legislation governing their affairs is the Aboriginal Peoples Ordinance 1954 (APA). ${ }^{106}$ It was enacted before independence following security concerns during a communist insurgency (1948-1960) involving the Orang Asli who were living in the forests and were used by

101 Anaya, Indigenous Peoples in International Law, 32-3.

102 Ibid., 31.

103 G C Marks, "Indigenous Peoples in International Law: The Significance of Francisco De Vitoria and Bartolomế De Las Casas," Australian Year Book of International Law 13 (1992) , 2-5; Anaya, Indigenous Peoples in International Law, 16-19.

104 Anthony Anghie, "Francisco De Vitoria and the Colonial Origins of International Law", in Laws of the Postcolonial, ed. Eve Darian-Smith and Peter Fitzpatrick (Ann Arbor: University of Michigan Press, 1999) , 89; Zion and Yazzie, "Indigenous Law in the Wake of Conquest" , 59-65.

Marks, "Indigenous Peoples in International Law: The Significance of Francisco De Vitoria and Bartolomế De Las Casas" citing Scott JB, "The Spanish Origin of International Law" (1932); Sanders, "The Re-Emergence of Indigenous Questions in International Law, " Canada Human Rights Yearbook 3 (1983), 12-30.

106 Ordinance No. 3 of 1954. The Ordinance was revised as the Aboriginal Peoples Act 1954 in 1974 (Act 134). 
communist guerrillas to supply their needs. ${ }^{107}$ This situation partly explains the extensive government control of the Orang Asli. The APA was adopted from Perak Aboriginal Tribes Enactment $1939^{108}$ which sought to address the development issues that were dispossessing the aboriginal people as well as the health and social problems faced by them. ${ }^{109}$

An administrative mechanism created by the APA was the position of 'Protector for Aborigines' ${ }^{110}$ which was the predecessor of the current position of the Director General of the Orang Asli. This office was similar to those created in Australia in 1837 whose duties were to safeguard 'the rights of the Aboriginal Peoples in terms of encroachment on their property and to protect them from acts of cruelty, oppression and injustice'. ${ }^{111}$

Under the APA, extensive powers are given to the Director General of Orang Asli Affairs concerning the administration, welfare and advancement of the Orang Asli. However, it was expressly stated that this position does not preclude the 'aboriginal headman from exercising his authority in matters of aboriginal custom and belief'. ${ }^{112}$ It also provides for the creation of Aboriginal Areas and Aboriginal Reserves which are given priority over other types of reserves, including Malay Reserves and animal sanctuaries. ${ }^{113}$ The APA also limits the power of the State authorities to alienate land or grant licenses affecting land declared as Aboriginal Areas by subjecting them to consultation with the Director General at Federal level. ${ }^{14}$

107 J. D. Leary, Violence and the Dream People: The Orang Asli in the Malayan Emergency, 1948-1960. (Athens, OH: Center for International Studies, Ohio University, 1995).

109 Noone, H D, "Report on the Settlements and Welfare of the Ple-Temiar Senoi of the Perak-Kelantan Watershed" Journal of the Federated Malay States Museums 19 (1) [1936], 1-85, cited in Rusaslina Idrus, "The Discourse of Protection and the Orang Asli in Malaysia," Malaysian Studies 29, no. Suppl. 1 (2011) , 60. Ibid., 60.

111 "House of Commons Select Committee on Aborigines (British Settlements) Report, Parl Paper, No 425," ed. House of Commons (1837), 84.

112 APA, S 4: "The Director General shall be responsible for the general administration, welfare and advancement of aborigines: Provided that nothing in this section shall be deemed to preclude any aboriginal headman from exercising his authority in matters of aboriginal custom and belief in any aboriginal community or any aboriginal ethnic group.

113 APA, s 6(2) and s 7(2).

114 APA, ss 6(2)(iii)-(iv). 
Alienation or grant of land within an Aboriginal Reserve could only be made to aborigines who normally reside within the reserve. ${ }^{115}$ The same mechanism was taken by British in the Royal Proclamation 1763 that restricted conveyance of the Indian land to protect the Indians. The British policy later influenced the US government policy in dealing with the Indians in the US territories. For example, the Indian Intercourse Act adopted in 1790 controlled trade and travel in Indian territories and restricted conveyance of Indian lands without the consent of the US government. ${ }^{116}$

Further, at a policy level announced in 1957 for the Orang Asli in the peninsula, the hereditary land rights of the various local groups will be recognised and that these local groups will not be forced to move against their will for any economic or political reasons. ${ }^{117}$ This statement affirmed the same line of policy and laws involving the administration of land of the Orang Asli.

\section{CONCLUSION}

This historical discussion on law and official practice in the North America, Indian Empire and the Malay Peninsula demonstrates the continuation of the underlying principle that acknowledged the rights of local peoples to lands and resources arising from customs. This could be traced in the British practice during the colonisation period particularly in India, which had direct influence in the administration of the Malay Peninsula. The theme was also consistent in other jurisdictions including Canada, the US, New Zealand and Australia. The practice of treaty-making and the introduction of English laws reflected regard for the local customs and religions of the local inhabitants, as well as their rights and interests.

During the colonial period, the local inhabitants in the Malay states were largely governed by their own laws and customs. Although a range of new laws were introduced, which initially was

\footnotetext{
115 APA, s 7(2)(iv).

116 Benjamin J. Richardson, "The Dyadic Character of US Indian Law", in Indigenous Peoples and the Law: Comparative and Critical Perspectives, ed. Benjamin J. Richardson, Shin Imai, and Kent McNeil (Oxford and Portland, Oregon: Hart Publishing, 2009), 59.

117 "The Long Term Administration of the Aborigines of Malaya 27 May 1957 Anm - 2005/0018322 (Malaysia National Archive), " (1957).
} 
intended for British subjects, the existing rights and interests of the inhabitants, their local customs and religions were maintained. Further, while reference to the common law and equity of England was provided by civil law enactments, it was intended to fill in the absence of local laws, albeit, in practice there was greater reliance on the English law by judges for various reasons.

In particular, it is also evident in history that the autonomy and control of the Orang Asli over their own territories were not denied. They regarded themselves as the original inhabitants of the territories that they lived in, independent of the Malay rulers. This was also observed during the British administration whereby the Orang Asli communities were regarded as distinct communities from the Malays, having autonomy and control over their own territories with their own customs and traditions regulating their affairs. This position was also inherently acknowledged by the laws and policies relating to land administration and Orang Asli affairs to date as could be seen in various legislations relating to the administration of land and forests as well as the specific legislation governing the affairs of the Orang Asli i.e. the APA.

Therefore, the principle inherent under the law, developed in the history, has shaped and laid the groundwork of the present law regulating land and forests in Malaysia, and thereby should also influence the meaning and interpretation of the relevant statutory provisions.

The fact of the matter is that there was no single provision in the law that expressly denies or relinquishes the existing rights of the Orang Asli to their customary land. But in reality, there were other factors that had led to the continued loss of land by the aborigines including conflicting economic interests and cultural attitude towards them. The recognition of indigenous peoples' rights was hampered by positivism that came to prevail both in international law and national legal systems. ${ }^{118}$ By the turn of the $20^{\text {th }}$ century which saw an unprecedented mass exploitation of land and forests, the view that certain positive laws as a priori was largely used to justify the expropriation of rural resources. In consequence, all legal rights were seen to emanate only from legislation. Societies deemed to be primitive, without the kind of government similar to those of European states, were considered to have no law. ${ }^{119}$ Increasingly, it

118 Anaya, Indigenous Peoples in International Law, 26.

119 H.L.A. Hart, The Concept of Law (1994). 
was believed that grants by state and registration were the only prerequisites to land entitlement. Alienation and reservation of land were also made without proper survey or due notification for interests to be claimed. Customary land holdings were regarded by many as only confined to Negeri Sembilan and Naning as they were codified by statutes. The Orang Asli began to be labelled more or less as 'squatters' on their own land. It became the prevalent perception that such communities had no land but were occupying state land.

On the contrary, even though the Orang Asli had continued to lose their authority, autonomy and territories in a span of almost two centuries, the principle of recognition of tribal dominium (ownership) stands and is alive. This imperial practice led to the development of the common law native title in common law jurisdictions including the United States, Canada and Australia. Under the persuasive authorities from these jurisdictions, Malaysian common law has also affirmed the common law principle that recognises the native title of the aboriginal peoples in the Malay Peninsula as well as the natives in East Malaysia.

From this perspective, the development in the Malaysian common law addressing the concerns of the Orang Asli and natives in the East Malaysia is not novel but merely the application of a long- standing principle in the jurisdiction. 